\title{
EMBER 2.0 - A MESTERSÉGES INTELLIGENCIA GAZDASÁGI ÉS TÁRSADALMI HATÁSAI
}

A mesterséges intelligencia témaköre évtizedek óta izgatja mind a fejlesztőket, mind pedig a kutatókat, egyre inkább látjuk azokat a szinte felmérhetetlen kulturális, társadalmi és gazdasági hatásokat, melyeket egyre terjedő alkalmazása okoz. Az infokommunikációs technológiák, a szenzorok és a nagy adattömegek gyors terjedése az utóbbi évtizedben sosem látott távlatokat nyitnak meg ezen lehetőségek valódi alkalmazása előtt, a technológia egyre inkább életre kel. Bár a témakör fontos, a szakszerü, magas perspektívából közelítő társadalom- és gazdaságtudományi munka mégis elenyészően kevés, ezek jobbjai is leginkább a technofób- és technofil gondolkodás egyirányú gondolatkörében mozognak. Ez a kötet tudományos hitelességében és széles látókörével, követhetö, megalapozott érvelésével hiánypótló, nemcsak a hazai, de a nemzetközi tudományosságban is.

A kötet négy nagy tematikus blokkból épül fel, az elsőben az evolúció és intelligencia, a másodikban a mesterséges intelligencia fejlesztése, a harmadikban ennek alkalmazásai, a negyedikben az Ember 2.0 témakörét járja körül a szerzö. A könyv szerkezete és gondolati íve világos, könnyen követhető, érződik, hogy egy kiforrott világszemlélet került leírásra és kiadásra. A stílus könnyed, jól olvasható, a téma nehézsége és összetettsége nem bénította meg a szerző tollát, de nem csúszott a felületes moralizálgatás figyelemfelkeltő, ámde valójában értéktelen csapdájába sem. A szöveg rendkívül sürü, egy-egy bekezdésével hetek, hónapok olvasottságát spórolja meg az olvasónak, illetve új összefüggéseket világít meg, számtalan aha élményt okozva ezzel. Széles körü irodalomhasználatával, sürü leírásával azt a csapdát is elkerüli a szerző, mely a napjainkban egyre inkább terjedő, érdekes, de mindig valamelyes hiány- vagy csúsztatásérzetet okozó cherry-picking jellegü népszerü tudományos munkákat jellemzi.

Az első tematikus blokkban az élettelenből keletkező életet az idővel, és az idővel dacoló információátadással kapcsolja össze. Az evolúciót folyamatnak, de nem szükségszerü folyamatnak érzékeli, ahol az egyre összetettebb biológiai (és később már populációs, illetve közösségi) megmaradás és fejlődés kulcsa az információátadás, mely segíti a környezethez való alkalmazkodást, illetve növeli a variabilitást. Az ember kiválása a főemlősök rendjéből az információ átadásának megkettőződését hozza magával, a genetikai kód mellett megjelenik az emberi nyelv. Az emberi nyelv több funkcióval bír, segítségével legyőzhető a tér és az idő, de formálható az agy, segíti a társas kapcsolatok szervezését, de segít elhatárolódni is más közösségektől. A nyelv szerepe után az intelligencia és a tudás szerepének elemzése következik, a szerző röviden bemutatja müködésének fo- 
lyamatmodelljét, szerepét a szelíd és vad problémák megoldásában, társadalmi jelentőségét. Az intelligencia csak akkor töltheti be szerepét az emberi alkalmazkodásban és túlélésben, hogyha beágyazódik a lét egészébe. Ebben a beágyazottságban realizálódnak az intelligencia adta kognitív lehetőségek. Itt már fel is teszi a szerző a kötet végén megválaszolandó kérdését, miszerint eljön-e az idő, amikor az emberi ész által alkotott gépi episztemológiai tudás felfalja a gépesíthetetlen axiológiai tudást. A mesterséges intelligencia és a tudat relációjában két kritikus fontosságú sarokpontot is felvet a szerző, egyrészt a szabad akarat, illetve önreferencialitás viszonyát a (mesterséges) intelligenciához, másrészt az intelligencia normális eloszlásának témakörét, melyet talán alapjaiban változtat meg a mesterséges intelligencia, a kettő együttesen pedig talán az Ember 2.0 kialakulásához, és ennek gyökeresen új lehetőségeihez vezethet. A szerző áttekinti a mesterséges intelligencia alapvető fejlesztésének történetét, az utóbbi évtizedekben összekapcsolva ezt a hálózatosodás, digitalizáció és a datafikáció szerepével, értelmezve a big data jelentőségét is ebben a fejlődésben. Ennek során kitér nemcsak az új társadalomtudomány kihívásaira, de a személyes identitás változásaira is. Bevezeti a gyenge (utánzó) és az erős (pótló) mesterséges intelligencia fogalompárját is, kiegészítve az algoritmusok, útvonaltervezések fontosságával a mesterséges intelligencia megértésében.

A második nagy tematikus blokk a mesterséges intelligencia fejlesztéséről szól. Az első szövegegységben felvázolt gondolati keretekben vizsgálja a mesterséges intelligencia újdonságait a bizonytalanságkezelés, a döntések, a tanulás, emlékezet és nyelv területein. Miben új, miben hasonló, és miben más a mesterséges intelligencia az eddigi biológiai és kulturális kódoknál? Ezek a fejezetek informatikai szaktudás nélkül is lehetővé teszik az olvasó számára, hogy megértse a mesterséges intelligencia átformáló, megváltoztató erejét, de korlátait is. A megoldandó problémák jellege szerint, Daniel Dennett alapján háromféle mesterséges intelligenciát különböztet meg, az orákulum (rutinszerü helyzeteket tudásvagyona alapján megválaszoló), a dzsinn (önálló cselekvésre képes) és az uralkodó (emberi kéz és agy beavatkozása nélkül müködő) típusokat. Végül, de nem utolsósorban nem maradhat ki a szuperintelligencia és a szingularitás fogalmainak tisztázása sem.

A harmadik szakaszban a mesterséges intelligencia alkalmazásának területeire vezet el a szerző világos fogalomhasználattal és esetekkel. Itt először az ember és a gép (illetve a gép által utánzott ember) Pygmalion-hatásig tartó kapcsolatát és lehetőségeit rajzolja meg, a következő fejezetben pedig a müvészet és a mesterséges intelligencia vizeire hajózik át, itt is kiemelve a lényeges különbséget a (tökéletes és gondolatébresztő) utánzás és az újítás között. A szerző ez után szisztematikusan áttekinti a társadalom és kommunikáció (új nyilvánosság, e-egészségügy, digitális állam, mindennapi élet, oktatás és kultúra, okos város) és a gazdaság (ipar 4.0, blokklánc, a munka értékének újraértelmezése, intelligens 
közlekedés) nagy, recens narratíváit, világosan és logikusan kontextusba helyezve és értelmezve azokat az olvasónak. Ezen fejezetek mindegyike az adott témakör kiváló bevezetése, értelmezése, ráadásul egymást kiegészítve, erősítve kerülnek kidolgozásra. Külön fejezetet kap a globális válságjelenségek kezelése, a totális ellenőrzés, a háborúk, a kiberdeviancia, és „természetesen” az etika és a jog területe is. Ennek a szisztematikus enumerációnak minden fejezete külön érték, együttesen pedig világossá teszik a mesterséges intelligencia által okozott változások összetettségét, lehetőségeit és kockázatait is.

Az első szakasz az értelmezési keretek kialakításáé, a második a történetiségé, a harmadik a jelen (és közeljövő) állapotáé, a negyedik pedig a távolabbi jövő fejezete. Visszatérve az evolúciós logikához ez az emberfeletti ember, az Ember 2.0 megjelenésében manifesztálódik a kötetben. Az alaposan elgondolkodtató, és nehezen cáfolható fejezet kiváló lehetőséget nyújt arra, hogy elvezessen a transzhumanizmus, poszthumanizmus területére is. A kötet az emberi emberért aggódó (társadalom)tudós gondolataival zárul.

Csepeli György könyve sürü leírással, alapos elmélyültséggel, mégis világosan érthető módon dolgoz fel egy olyan jelenségegyüttest, mely értelmezésében nemcsak az emberiség jelenéről, de múltjáról és jövőjéről is szól, megszólítja a mindegyik iránt érdeklődőket. A szerző feszessége a megfelelő megközelítési szint megragadásában és megtartásában lehetővé tette, hogy mind a szaktudomány, mind az egyetemi oktatás, mind pedig az érdeklődő nagyközönség számára hiteles, érdekes és hasznos kötetet foghatnak a kezükbe.

(Csepeli György: Ember 2.0 - A mesterséges intelligencia gazdasági és társadalmi hatásai. Budapest: Kossuth Kiadó, 2020, 270 o.)

Rab Árpád

PhD, egyetemi docens, Budapesti Corvinus Egyetem 